Abstracta Iranica

Revue bibliographique pour le domaine irano-aryen

Volume 27 | 2006

Comptes rendus des publications de 2004

\title{
« Pasargadai (Pasargades) ». Reallexikon der Assyriologie 10/5-6, pp. 351-363.
}

\section{Astrid Nunn}

\section{(2) OpenEdition}

1 Journals

\section{Édition électronique}

URL : http://journals.openedition.org/abstractairanica/5687

DOI : 10.4000/abstractairanica.5687

ISSN : 1961-960X

Éditeur :

CNRS (UMR 7528 Mondes iraniens et indiens), Éditions de l'IFRI

\section{Édition imprimée}

Date de publication : 15 mai 2006

ISSN : 0240-8910

\section{Référence électronique}

Astrid Nunn, « «Pasargadai (Pasargades) ». Reallexikon der Assyriologie 10/5-6, pp. 351-363. », Abstracta Iranica [En ligne], Volume 27 | 2006, document 63, mis en ligne le 02 janvier 2007, consulté le 25 septembre 2020. URL : http://journals.openedition.org/abstractairanica/5687 ; DOI : https:// doi.org/10.4000/abstractairanica.5687

Ce document a été généré automatiquement le 25 septembre 2020.

Tous droits réservés 


\section{« Pasargadai (Pasargades)». Reallexikon der Assyriologie 10/5-6, pp. 351-363.}

\section{Astrid Nunn}

1 L'article débute avec l'étymologie ainsi que l'historique des recherches et des fouilles. Pasargades sous Cyrus II, puis Pasargades de Darius I à Alexandre forment les deux grandes parties du texte. Des cartes, des plans et des reconstructions, ainsi celle du palais de Darius sur le lieu dit de Takht-i Soleiman, l'accompagnent. La tombe de Cyrus et la tour du Zendan-i Soleiman sont évoquées. Le Reallexikon est censé informer de manière brève mais exhaustive. En ce sens il pallie le triste manque de monographies accessibles sur les grands sites du Proche Orient ancien. Cet article emplit pleinement cette fonction.

\section{INDEX}

Thèmes : 3.2.1. Elam

\section{AUTEURS}

ASTRID NUNN

Université de Munich 